\title{
Fate of space station hangs on nominations of US Congress
}

Washington. A final decision on the future of the space station Freedom is fated to drop into the unsteady hand of the US Congress after a three-month redesign process demanded by President Clinton ended inconclusively.

Clinton was expected to identify one option for further investigation earlier this week. When the White House instigated the redesign process just over three months ago, officials let it be known that failure

\section{IMAGE UNAVAILABLE FOR COPYRIGHT REASONS}

\author{
Option A for Space Station Freedom \\ redesign (above); Daniel S. Goldin, NASA \\ administrator (right).
}

to meet a budgetary ceiling of $\$ 9$ billion for a permanently manned facility would result in withdrawal of support for the programme.

On its completion last week, the redesign process yielded three options ranging in cost from $\$ 11.9$ to $\$ 13.3$ billion. Uncertainty now arises because the numbers are not so far above the ceiling set by the president that he will be compelled to make a clear-cut decision to end the programme, in the process offending important constituencies in California and Texas and leaving blood on his hands.

The redesign, conducted at breakneck speed by engineers of the National Aeronautics and Space Administration (NASA), examined the feasibility of three options. Option A is a version of the Space Station Freedom with a much simpler and less ambitious control system, and possibly supported by an existing, military satellite called Bus-1. Option B is a shrunken version of Freedom that retains its basic design and therefore uses the design elements on which NASA has already expended $\$ 9$ bil- lion of taxpayers' money. Option C, the "man in the can", is a fresh non-modular design - although its supporters claim that much of the $\$ 9$ billion so far spent on Freedom has been invested in systems engineering work that would still be relevant if $\mathrm{C}$ were chosen.

The space station lobby and its adherents in Congress, led by George Brown (Democrat, California), chair of the House of Representatives' Science, Space and Technology Committee, have made clear their strong support for continuity, as expressed in Option B. Some congressmen held last week that $B$ is the only option that could gather a sufficiently strong coalition of support in Congress to survive.

Expert opinion seems to contradict that view. A special panel under the chairmanship of $\mathrm{Dr}$ Charles M. Vest, president of the

\section{IMAGE UNAVAILABLE FOR COPYRIGHT REASONS}

Massachusetts Institute of Technology, met last week to advise the president on the outcome of the redesign. Vest concluded that B "carried unnecessary system complexity" and said that the choice should be between $\mathrm{A}$ and $\mathrm{C}$.

This development left space station supporters rallying to the less-feared Option A. Brown, who has been meeting the president's science adviser Dr John Gibbons, issued a statement last Friday saying that "there will be room for compromise among the differing points of view".

Option C is regarded with suspicion by Freedom supporters because it appears to reverse the entire principle of a modular, expandable and international space station. It also upsets the international partners on the project: by providing much more rack space for scientific experi- ments than Freedom, it renders the Japanese contribution, which has already cost $\$ 900$ million, superfluous as well as incompatible.

But NASA administrator Dan Goldin, who was brought in from private industry to shake up the much-maligned administration, is said strongly to favour C. At a congressional hearing last week, he was asked by Sam Johnson (Republican, Texas) why, if he was neutral as he claimed, the slides for Option $\mathrm{C}$ were in colour and the others in black and white. Goldin said he had not prepared the graphics himself.

In a stormy session before the science subcommittee, Goldin was repeatedly pressed by James Sensenbreener (Republican, Wisconsin) on an allegation that he had ordered the destruction of charts showing the consequences of the three options on jobs in the aerospace industry. Goldin said - four times - that he "did not recall" giving such an order.

Whichever option is chosen, the president's advisory panel says that the orbital inclination of the space station should be raised from 28.8 degrees to 51.6 degrees, which will make it accessible to Russian launch sites, but will reduce the payload which the US space shuttle can carry to the station.

The space lobby is banking on heavier Russian participation in the programme to reduce costs. One possibility would be to merge the modular Option A with the Russian's proposed Mir 2 station, due for launch in 1997. A less likely choice would be to involve Russians in the construction and launch the 'big can' of Option C, which might save money but would further undermine congressional support.

Supporters of the programme are now very much on the defensive. Some sympathetic congressmen are even falling back on familiar warnings that withdrawal from the project would leave the Russians in the driving seat of manned space exploration.

The future of the space station will now rest on a series of debates in Congress, beginning this week with a debate on the floor of the House of Representatives, when opponents of the project plan to move to kill it.

If Clinton publicly withdraws his support for the space station, the project will almost certainly die. But if he continues to offer muted support for it, the question may drift on until August, and will be decided by the key budget votes that must at that point be taken.

Colin Macilwain 